\title{
PERANCANGAN SISTEM INFORMASI PELAYANAN PUBLIK PADA RUKUN WARGA 05 CENGKARENG TIMUR DENGAN PENERAPAN METODE NAÏVE BAYES
}

\author{
Meliana1 dan Riri Fajriah $^{2}$ \\ ${ }^{1}$ Jurusan Sistem Informasi, Fakultas Ilmu Komputer, Universitas Mercu Buana \\ 2Jurusan Sistem Informasi, Fakultas Ilmu Komputer, Universitas Mercu Buana \\ melianapanjaitan@gmail.com ${ }^{1}$,riri.fajriah@mercubuana.ac.id ${ }^{2}$
}

\begin{abstract}
Public service is a service provided by the government as the state administrator of the community to meet the needs of the community itself and has a purpose to improve the welfare of the community. The forms of service that are in the neighborhood of Citizenship 05 include basic administrative services, for example:services for making Family Cards, Birth Certificates, Death Letters, KTPs, Not Available Certificate (SKTM) and many others. The problem faced by the pillars of 05 is the administration and bureaucracy that have not been computerized, causing public services to be long. In addition, there are still many public service irregularities in the Rukun Warga 05, especially in the deviation from giving an insufficient certificate. Previous research on poor SKTM recipients in Jambi City was one of the bases of this research. The design of the public service information system in the RW 05 area was designed using several modules, namely the citizen reporting module, $R W$ work program evaluation module, $R T$ work program distribution module, citizen administration module, evaluation of SKTM giving, socialization module and citizen information. The implementation of this public service uses a prototype method and uses PIECES analysis with the application of naive bayes for selection of inadequate certificates so that public services and the provision of SKTM can be done effectively, efficiently and on target.
\end{abstract}

Keywords: Nä̈ve Bayes, PIECES, Services Public, SKTM, Web

\begin{abstract}
ABSTRAK
Pelayanan public merupakan pelayanan yang diberikan oleh pemerintah sebagai penyelenggara negara terhadap masyarakat untuk memenuhi kebutuhan masyarakat itu sendiri dan memiliki tujuan untuk meningkatkan kesejahteraan masyarakat. Bentuk-bentuk pelayanan yang ada di lingkungan Rukun Warga 05 meliputi pelayanan administrasi dasar misalnya: layanan pembuatan Kartu Keluarga, Akta Kelahiran, Surat Kematian, KTP, Surat Keterangan Tidak Mampu (SKTM) dan masih banyak yang lainnya. Masalah yang dihadapi oleh rukun warga 05 adalah adanya administrasi dan birokrasi yang belum terkomputerisasi sehingga menyebabkan pelayanan publik ke masyarakat menjadi lama. Selain itu juga dalam pelaksanaannya masih banyak terjadi penyimpangan-penyimpangan pelayanan publik di Rukun Warga 05 khususnya dalam penyimpangan pemberian surat keterangan tidak mampu. Penelitian terdahulu tentang warga miskin penerima SKTM di kota jambi menjadi salah satu yang melandasi penelitian ini. Perancangan sistem informasi pelayanan publik pada $R W 05$ dirancang dengan menggunakan beberapa modul yaitu modul pelaporan warga, modul evaluasi program kerja $R W$, modul distribusi program kerja RT, modul administrasi warga, evaluasi pemberian SKTM, modul sosialisasi dan informasi warga. Implementasi dari pelayanan publik ini menggunakan metode prototype dan menggunakan analisa PIECES dengan penerapan naive bayes untuk penyeleksian surat keterangan tidak mampu sehingga pelayanan publik dan pemberian SKTM dapat dilakukan secara efektif, efisien dan tepat sasaran.
\end{abstract}

Kata Kunci: Naive Bayes, Pelayanan Publik, PIECES, SKTM, Web 


\section{PENDAHULUAN}

\subsection{Latar Belakang}

Pelayanan publik merupakan pelayanan yang diberikan oleh pemerintah sebagai penyelenggara negara terhadap masyarakat guna memenuhi kebutuhan untuk masyarakat itu sendiri dan memiliki tujuan untuk meningkatkan kesejahteraan masyarakat [1]. Hal ini memberikan pemahaman bahwa segala sesuatu yang berkaitan dengan pelayanan hendaklah dilakukan dengan sebaik mungkin agar masyarakat yang menerima pelayanan tersebut merasa puas sehingga tujuan dari pelayanan tersebut dapat terwujud. Selain itu juga pelayanan publik harus memiliki kualitas pelayanan yang dapat mendorong dan meningkatkan kesejahteraan masyarakat.

Rukun Warga 05 merupakan salah satu Rukun Warga yang ada di Kelurahan Cengkareng Timur, Kecamatan Cengkareng, Jakarta Barat. Pelayanan yang telah diberikan oleh Rukun warga ini meliputi pelayanan administrasi dasar misalnya: layanan pembuatan Kartu Keluarga, Akta Kelahiran, Surat Kematian, KTP, Surat Keterangan Tidak Mampu (SKTM) dan masih banyak yang lainnya. Ada 15 Rukun Tetangga (RT) dibawah naungan RW 005 Cengkareng Timur. Ada beberapa program kerja/kegiatan yang ada di lingkungan Rukun Warga 05 diantaranya adalah kerja bakti, pelaksanaan PSN, Posyandu, pengajian ibu-ibu, pengajian bapak-bapak, arisan ibu-ibu, senam pagi, paguyuban melati dan penyantunan anak yatim piatu.

Program dan kegiatan tersebut dapat terjadi dengan baik apabila pengurus RT/RW berperan aktif dalam mengkoordinasikan dan mensosialisasikan informasi kepada masyarakat, memelihara kerukunan hidup warga dan membantu menjalankan tugas pelayanan kepada masyarakat. Selain itu juga, pengurus RW harus terus meningkatkan kualitas pelayanan publik dilihat dari peningkatan dari segi keahlian dalam hal administrasi pembangunan dan birokrasi, pemberdayaan masyarakat, problem solving serta peningkatan kesejahteraan pengurus dan masyarakat. Administrasi dan birokrasi yang ada di lingkungan RW 05 belum terkomputerisasi sehingga masih sering terjadi kesalahan dalam penyelenggaraan administrasi, salah satu contohnya yaitu penyalahgunaan pemberian surat keterangan tidak mampu (SKTM) kepada masyarakat. Selain itu juga belum optimalnya kinerja pengurus RW dalam menjalankan tugas dan fungsinya. Pembinaan administrasi RT/RW merupakan upaya peningkatan kualitas penyelenggaraan administrasi yang efektif, efisien, berdaya guna dan berhasil guna untuk mendukung kelancaran penyelengaraan kegiatan di lingkungan RT/RW.

Untuk meningkatkan pelayanan administrasi dan birokrasi di lingkungan RW 05 yang belum terkomputerisasi diperlukan adanya sistem manajemen administrasi integrasi berbasis elektronik dalam tata kelola pelayanan. Diharapkan dengan adanya sistem manajemen administrasi yang berbasis web dapat meningkatkan pelayanan publik terhadap masyarakat. Ada beberapa kendala yang terjadi dalam pelayanan publik di wilayah rukun warga 05 , diantaranya adalah :

a. Kebutuhan untuk dapat menyimpan format dan distribusi surat-surat yang dibutuhkan oleh masyarakat secara cepat yang tersimpan dalam suatu database

b. Sering terjadi penyalahgunaan pemberian surat keterangan tidak mampu (SKTM)

c. Kesulitan dalam mengevaluasi hasil pencapaian kinerja masing-masing RT dibawah koordinasi RW 05

d. Kendala dalam merancang solusi sistem informasi manajemen administrasi terintegrasi berbasis elektronik dalam tata pelayanan para rukun tetangga dibawah koordinasi RW 05

e. Diperlukan adanya rancangan suatu sistem informasi yang memudahkan warga masyarakat RW 05 dalam pelaporan mengenai pelayanan dan ketertiban lingkungan di wilayah RW 05

Berdasarkan latar belakang permasalahan diatas, maka penulis tertarik mengambil judul "Perancangan Sistem Informasi Pelayanan Publik Pada Rukun Warga 05 Cengkareng Timur Dengan Penerapan Metode Naive Bayes".

\subsection{Tujuan Penelitian}

Adapun tujuan yang ingin dicapai dari penelitian ini adalah :

1. Untuk mengevaluasi pencapaian kerja RW 05

2. Memberikan pelayanan publik yang lebih baik dengan cara merancang suatu sistem informasi manajemen administrasi yang berbasis elektronik 
3. Pemberian surat keterangan tidak mampu secara efektif dan tepat sasaran

4. Administrasi dan birokrasi dalam penyimpanan file-file dan distribusi surat-surat dapat disimpan dalam suatu database

5. Pelaporan mengenai pelayanan publik dapat diatasi dengan cepat dan lebih terarah

\subsection{Review Penelitian/Penelitian Terdahulu}

Berdasarkan penelitian terdahulu yang telah dilakukan mengenai surat keterangan tidak mampu (SKTM), dapat diketahui bahwa penelitian menghasilkan sistem pendukung keputusan yang digunakan untuk pemilihan warga miskin penerima SKTM dengan menggunakan perhitungan metode Sample Additive Weighting (SAW) dengan memanfaatkan kriteria-kriteria dasar kemiskinan yaitu pendapatan, tempat tinggal, sandang, pangan, kesehatan dan pendidikan [2].

Penelitian lain yang telah dilakukan menjelaskan bahwa untuk membantu mengatasi permasalahan dalam pelayanan administrasi kependudukan dengan membuat suatu sistem pelayanan administrasi kependudukan berbasis web sehingga akan memudahkan masyarakat. Selain itu juga sistem ini dirancang untuk dapat memproses mutasi kependudukan (kelahiran dan kematian) serta dapat menyimpan surat-surat yang pernah diproses kemudian dapat ditampilkan dalam bentuk laporan yang dapat dicetak [3].

Penelitian terkait yang telah dilakukan menjelaskan bahwa permasalahan yang terjadi dikarenakan sistem yang digunakan dalam penentuan kelayakan calon tenaga kerja masih manual sehingga mengakibatkan kelayakan calon tenaga kerja kurang efektif. Dalam penentuan kelayakan calon tenaga kerja ditentukan dengan menggunakan metode naive bayes sehingga dapat mempermudah dalam penyeleksian calon tenaga kerja. Selain itu juga dirancang suatu sistem aplikasi seleksi calon tenaga kerja sehingga dengan menggunakan aplikasi tersebut dapat dengan mudah dan cepat dalam memasukan data pendaftar, dapat langsung menerima laporan data pendaftar diterima atau tidak [4].

Permasalahan lain yang terjadi yaitu sulitnya dalam menentukan kualitas jeruk yang diekspor menjadi dasar dari penelitian ini. Dengan menggunakan metode naive bayes dan dirancang suatu sistem maka dapat dengan mudah dan cepat dalam menentukan kualitas jeruk yang akan diekspor [5].

Berdasarkan penelitian terdahulu mengenai pengelolaan sistem parkir, dapat diketahui bahwa penelitian ini menghasilkan informasi mengenai aktivitas parkir yang bermanfaat untuk memonitoring kondisi lahan parkir di lapangan. Penelitian ini menggunakan metode prototyping dan pengembangan dengan model waterfal sehingga dengan pengembangan tersebut dapat menghasilkan suatu pengelolaan informasi yang bisa digunakan dalam pengembangan sistem parkir lebih lanjut [6].

Penelitian lain yang telah dilakukan yaitu mengenai pengembangan web e-commerce dengan metode prototype dimana permasalahan yang ada yaitu kurangnya informasi ketersediaan jadwal perusahaan untuk melayani pesanan pada tanggal tertentu dan proses pesanan hanya dilayani pada saat jam kerja saja. Aplikasi web yang dirancang menghasilkan suatu proses pemesanan dan validasi pembayaran dapat dilakukan dengan mudah serta dapat memberikan informasi tanpa terhalang oleh jarak dan waktu. Web e-commerce tersebut dapat memenuhi kebutuhan perusahaan dan penyebaran informasi dapat dilakukan dengan mudah sehingga dapat menghemat pengeluaran biaya operasional [7].

Penelitian ini menghasilkan suatu sistem informasi IT asset management, EUC dapat mengelola pinjaman alat kerja karyawan melalui aplikasi web yang penyimpanan berkasberkas/dokumennya secara digital sehingga file akan lebih mudah dikelola ketika ingin dicari atau dibutuhkan dan permintaan staff cepat terpenuhi. Penelitian ini menggunakan metode prototyping dengan framework code igniter [8].

Proses evaluasi kinerja dosen masih dilakukan secara manual dengan menggunakan kertas kuesioner yang dibagikan ke mahasiswa. Metode penelitian ini dilakukan dengan menggunakan metode ELECTRE sehingga menghasilkan suatu proses evaluasi dosen dapat dilakukan secara online dalam perankingan kinerja dosen [9]. 


\section{METODE PENELITIAN}

Adapun metodelogi peneltian yang digunakan dalam perancangan sistem pelayanan publik pada Rukun Warga 05 Cengkareng Timur adalah sebagai berikut :

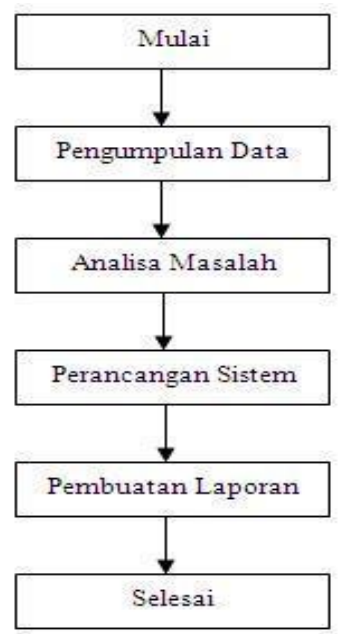

Gambar 1. Diagram Alir Metodelogi Penelitian

Metodelogi yang digunakan dalam penelitian ini terdiri dari pengumpulan data (wawancara, observasi, studi literature), analisa masalah (prototype, pieces, naive bayes), perancangan sistem (UML, Basis Data, Web) pembuatan laporan dan kesimpulan. Metodelogi pengembangan sistem menggunakan metode prototype dimana terdapat beberapa tahapan yang harus dilalui yaitu komunikasi, perencanaan cepat, pemodelan design cepat, pembentukan prototype serta penyerahan sistem ke pengguna dan umpan balik [10].

Metode pengumpulan data dilakukan dengan wawancara dengan ketua RW mengenai pelayanan publik, observasi atau pengamatan langsung terhadap proses pelayanan publik yang terjadi di lingkungan RW dan studi pustaka. Tahap analisa masalah akan dilakukan dengan menggunakan analisa pieces dan perancangan sistem menggunakan metode UML dengan membuat use case diagram, activity diagram, sequence diagram serta rancangan interface. Selain itu juga pada tahap analisa masalah untuk penyeleksian suatu kriteria masalah dilakukan dengan metode naive bayes. Selanjutnya akan dilakukan proses perancangan suatu database dengan cara membuat class diagram dan pengembangan aplikasi menggunakan bahasa pemrograman PHP serta dengan dukungan database MySql. Setelah tahap perancangan sistem, tahap berikutnya adalah pembuatan laporan.

\section{HASIL DAN PEMBAHASAN}

\subsection{Analisa Masalah}

\section{PIECES}

Dalam melakukan analisa masalah, penelitian ini menggunakan metode analisis PIECES. Metode analisa pieces digunakan Sebagai dasar untuk memperoleh pokok-pokok permasalahan yang lebih spesifik. 
Tabel 1. Tabel Analisa PIECES

\begin{tabular}{|c|c|c|}
\hline Analisa & Kendala & Solusi \\
\hline $\begin{array}{l}\text { Performance } \\
\text { (Kinerja) }\end{array}$ & $\begin{array}{l}\text { - Administrasi atau birokrasi belum } \\
\text { terkomputerisasi } \\
\text { - File-file data warga belum } \\
\text { tersimpan di database } \\
\text { - Masih terjadi penyimpangan surat } \\
\text { keterangan tidak mampu }\end{array}$ & $\begin{array}{l}\text { - Dirancang suatu aplikasi web } \\
\text { - File-file data warga disimpan } \\
\text { dalam suatu database } \\
\text { - Meminimalisir akan terjadinya } \\
\text { penyalahgunaan SKTM }\end{array}$ \\
\hline $\begin{array}{l}\text { Information } \\
\text { (Informasi) }\end{array}$ & $\begin{array}{l}\text { Informasi secara tertulis di papan } \\
\text { pengumuman }\end{array}$ & - Dapat dilihat dengan akses web \\
\hline Economy (Ekonomi) & $\begin{array}{l}\text { - Dokumentasi kurang aman dan } \\
\text { kurang baik } \\
\text { - Biaya sulit dilacak ke sumber } \\
\text { - Rekonsiliasi biaya operasional sulit } \\
\text { - Kesulitan dalam perencanaan } \\
\text { anggaran oprasional }\end{array}$ & $\begin{array}{l}\text { - Dokumentasi tersimpan dengan } \\
\text { aman dan baik } \\
\text { - Biaya akan lebih mudah diperiksa } \\
\text { - Perencanaan anggaran lebih } \\
\text { efektif dan efisein }\end{array}$ \\
\hline $\begin{array}{l}\text { Control } \\
\text { (Pengendalian) }\end{array}$ & $\begin{array}{l}\text { - Kurang dapat kontrol } \\
\text { - Keamanan kurang } \\
\text { - Proses transaksi lambat } \\
\text { - Resiko human error }\end{array}$ & $\begin{array}{l}\text { - Dapat dikontrol dengan baik } \\
\text { - Keamanan dapat dikontrol dengan } \\
\text { baik } \\
\text { - Proses transaksi cepat }\end{array}$ \\
\hline Efficiency (Efisien) & $\begin{array}{l}\text { - Pekerjaan memakan waktu yang } \\
\text { lama }\end{array}$ & - Pekerjaan lebih cepat selesai \\
\hline Service (Layanan) & $\begin{array}{l}\text { - Lama dalam melayani permintaan } \\
\text { warga apabila banyak yang } \\
\text { mengurus a dministrasi ke RW } \\
\text { - Sulit dalam mencari data warga }\end{array}$ & $\begin{array}{l}\text { - Lebih cepat dalam melayani } \\
\text { permintaan warga } \\
\text { - Lebih mudah dalam mencari data } \\
\text { warga }\end{array}$ \\
\hline
\end{tabular}

\section{Naïve Bayes}

Naive Bayes merupakan metode yang membagi permasalahan ke dalam sebuah kelaskelas berdasarkan ciri-ciri persamaan dan perbedaan dengan menggunakan statistik yang bisa memprediksi probabilitas sebuah kelas [11]. Naïve Bayesian kalsifikasi adalah suatu klasifikasi berpeluang sederhana berdasarkan aplikasi teorema bayes dengan asumsi antar variabel perjelas saling bebas (independen). Dalam hal ini, diasumsikan kehadiran atau ketiadaan dari suatu kejadian tertentu dari suatu kelompok tidak berhubungan dengan kehadiran atau ketiadaan dari kejadian lainnya. Penelitian ini menggunakan metode naive bayes dalam penerapannya yang digunakan untuk memprediksi pemberian surat keterangan tidak mampu pada wilayah Rukun Warga 05 Cengkareng Timur.

Tabel 2. Kriteria dan Sub criteria

\begin{tabular}{|c|l|c|}
\hline No & Kriteria & Nilai \\
\hline 1 & Domisili & \\
\hline & $\leq 5 \mathrm{Km}$ & $86-100$ \\
\hline & $5 \mathrm{Km}-10 \mathrm{Km}$ & $70-85$ \\
\hline & $\geq 10 \mathrm{Km}$ & $0-69$ \\
\hline 2 & Pekerjaan & $86-100$ \\
\hline & Tidak Bekerja & $76-85$ \\
\hline & Pelajar atau Mahasiswa & $66-75$ \\
\hline & Pegawai Swasta & $51-65$ \\
\hline & Wiraswasta & $0-50$ \\
\hline & Pegawai Negeri Sipil & \\
\hline 3 & Kelengkapan Berkas berupa KTP, KK, Surat Keterangan & $86-100$ \\
\hline & Tidak Mampu dan Surat Pengantar RT/RW & $70-85$ \\
\hline & Ada semuanya & $0-69$ \\
\hline & Hanya salah satusaja & \\
\hline & Tidak ada semuanya & \\
\hline
\end{tabular}




\begin{tabular}{|c|l|c|}
\hline 4 & Keperluan Pengurusan Surat & \\
\hline & Pendidikan & $86-100$ \\
\hline & Kesehatan & $71-85$ \\
\hline & Modal usaha & $51-70$ \\
\hline & Sandang, pangan dan papan & $0-50$ \\
\hline 5 & Penghasilan & \\
\hline & $\leq 1.000 .000$ & $91-100$ \\
\hline & $1.000 .000-2.000 .000$ & $76-90$ \\
\hline & $2.000 .000-3.000 .000$ & $61-75$ \\
\hline & $\geq 3.000 .000$ & $0-60$ \\
\hline
\end{tabular}

Sumber : Rukun Warga 05 Cengkareng Timur

\section{Menghitung Nilai Likehood}

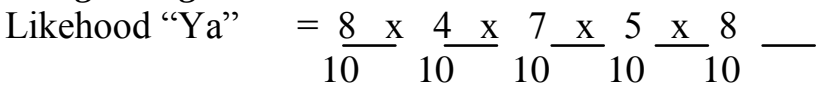

$$
\begin{aligned}
& =\frac{8960}{100000}=0.0896 \\
& \text { Likehood "Tidak" = } \begin{array}{llllllrrr}
3 & x & 1 & x & 4 & x & 6 & x & 3 \\
10 & 10 & 10 & 10
\end{array} \\
& =\frac{216}{100000}=0.00216 \\
& \text { Probablilitas "Ya" }=\frac{0.0896}{0.0896+0.00216}=0.0918=0.9760 \\
& \text { Probabilitas "Tidak" }=\frac{0.00216}{0.0896+0.00216}=0.00216=0.0235
\end{aligned}
$$

\section{Menghitung Nilai Probabilitas}

\subsection{Perancangan Sistem}

Perancangan sistem bertujuan untuk memberikan gambaran yang jelas dan menghasilkan rancang bangun dalam sistem pelayanan publik pada wilayah Rukun Warga 05. Perancangan dilakukan berdasarkan hasil analisa masalah yang telah dilakukan sebelumnya. Proses perancangan sistem dalam penelitian ini menggunakan pemodelan sistem UML (Unified Modelling Language) seperti use case, activity diagram, sequence diagram dan class diagram.

\section{Use Case Diagram}

Berdasarkan permasalahan yang terjadi pada Rukun Warga 05, maka dibuat suatu analisa masalah sistem dalam skema use case usulan sebagai berikut :

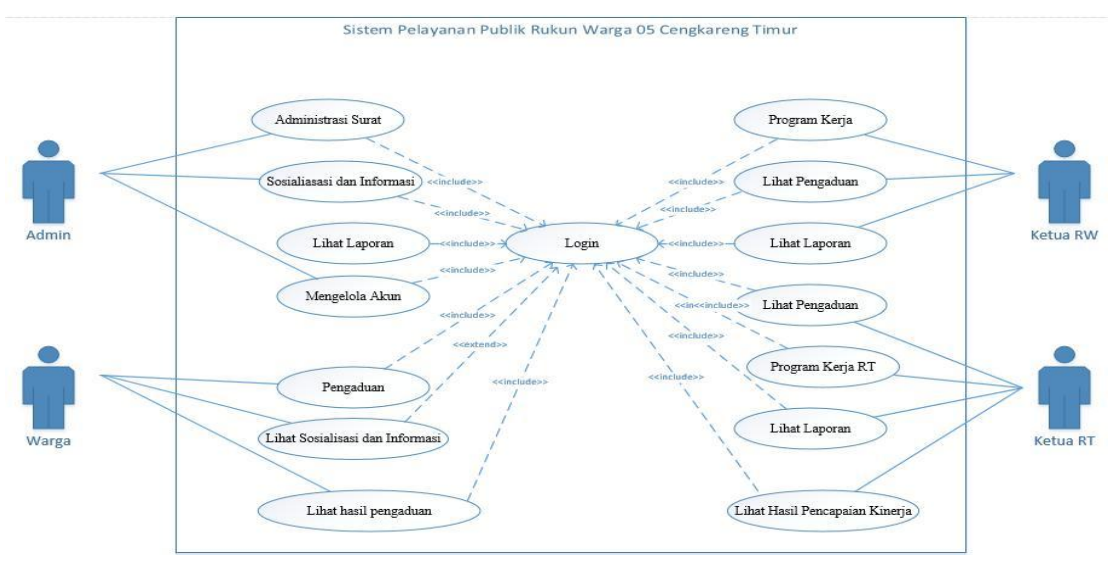

Gambar 2. Use Case Diagram 
Dapat kita lihat melalui penggambaran use case diagram diatas adalah sebagai berikut :

a. Perancangan sistem pada pelayanan publik yang dibangun akan melibatkan beberapa actor yang akan mengoperasikan sistem ini, yaitu : sekretaris, warga, ketua rw dan ketua rt.

b. Proses-proses yang akan dijalankan/dilakukan adalah sebagai berikut :

1. Admin

Admin merupakan actor yang mempunyai hak untuk input data warga, administrasi surat warga, melihat laporan, sosialisasi dan infromasi serta kelola akun user.

2. Warga

a. Input pengaduan warga

b. Melihat sosialisasi dan informasi warga

c. Lihat hasil pengaduan/pelaporan warga

3. Ketua RW
a. Melihat laporan
b. Mengevalausi kinerja RT
c. Melihat pengaduan warga

4. Ketua RT
a. Input program kerja dan Lihat hasil pencapaian kinerja
b. Melihat pengaduan
c. Lihat laporan

\section{Activity Diagram}

Activity Diagram digunakan untuk menggambar aktivitas yang ada didalam suatu proses bisnis. Activity diagram dapat digunakan untuk menggambarkan alur kerja yang terdapat dalam use case hingga rincian spesifik use case [12]. Salah satu contoh dari activity diagram adalah sebagai berikut :

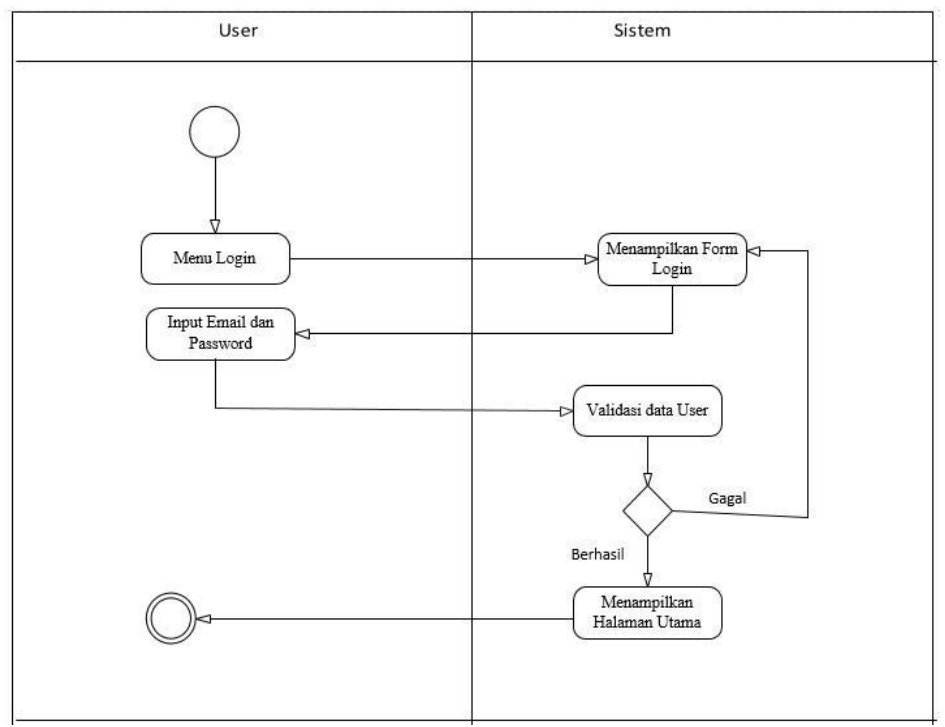

Gambar 3. Activity Diagram Menu Login

Pada gambar diatas menunjukkan aktivitas-aktivitas yang dilakukan oleh actor/user. Langkah pertama dari activity diagram ini adalah user masuk ke menu login. Sistem akan menampilkan form login setelah itu user input username dan password. Kemudian sistem akan memvalidasi data, jika data yang diinput oleh user lengkap/valid maka sistem akan menyimpan data-data yang telah diisi oleh user dan sistem menampilkan halaman utama tetapi jika data-data yang diisi oleh user tidak valid/tidak lengkap, maka sistem menampilkan pesan untuk user melengkapai data-data tersebut. 


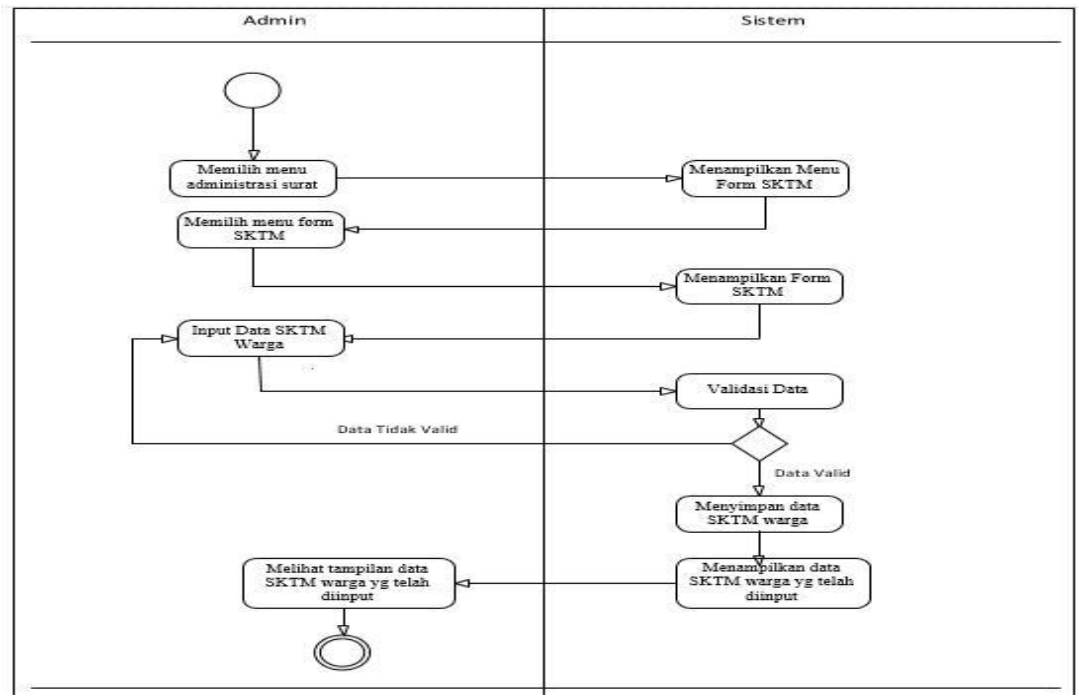

Gambar 4. Activity Diagarm Menu SKTM

Berikut penjelasan tentang activity diagram administrasi surat SKTM :

a. Admin memilih menu administrasi surat

b. Sistem menampilkan menu form SKTM

c. Admin memilih menu form SKTM

d. Sistem menampilkan form SKTM

e. Admin input data SKTM warga

f. Sistem memvalidasi data, jika data belum lengkap maka sistem akan menampilkan pesan untuk melengkapi data-data tersebut

g. Jika data lengkap maka sistem menyimpan data-data warga, setelah itu admin dapat melihat tampilan data SKTM warga yang sudah diinput

\section{Sequence Diagram}

Sequence diagram adalah diagram yang menampilkan hubungan interaksi antar objek didalan sistem yang disusun berdasarkan urutan waktu [12]. Sequence diagram pada penelitian ini digambarkan sebagai berikut :

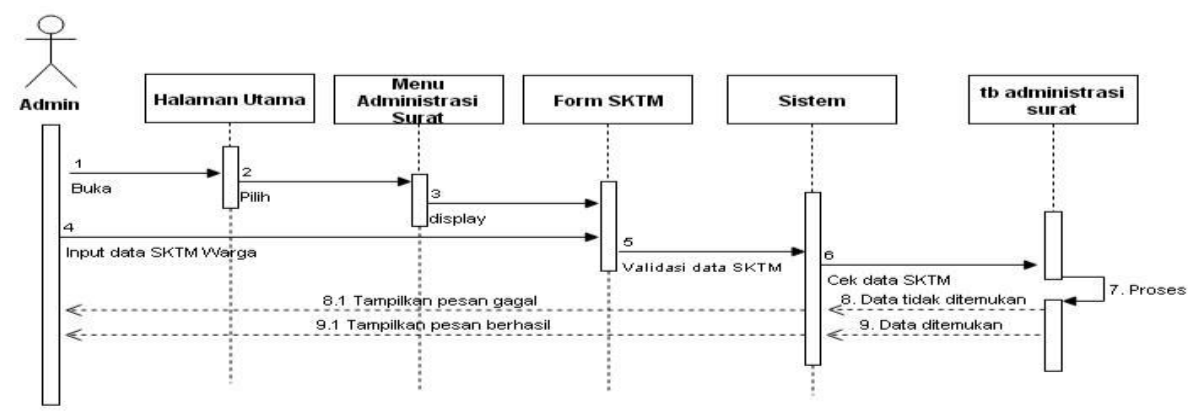

Gambar 5. Sequence Diagram Menu SKTM

Berikut penjelasan dari sequence diagram administrasi SKTM:

1. Admin membuka menu halaman utama dan menampilkan halaman menu administrasi surat

2. Admin memilih menu administrasi surat

3. Sistem menampilkan form SKTM

4. Admin menginput data SKTM

5. Sistem memvalidasi data SKTM yang telah diinput oleh admin

6. Sistem akan mengecek data SKTM pada tb administrasi surat 
7. Sistem memproses data tersebut

8. Jika data yang diinput tidak valid maka sistem akan menampilkan pesan gagal

9. Jika data yang diinput valid maka sistem akan menampilkan pesan berhasil dan sistem menyimpan data tersebut

\section{Class Diagram}

Class diagram nerupakan model statis yang menggambarkan kelas dan relasi antar kelas yang konstan dalam sistem dari waktu ke waktu. Class diagram menggambarkan kelas mencakup prilaku dan kedudukan dengan hubungan antar kelas [12]. Gambar dibawah ini menunjukan rancangan basis data dalam bentuk class diagram seperti began dibawah ini :

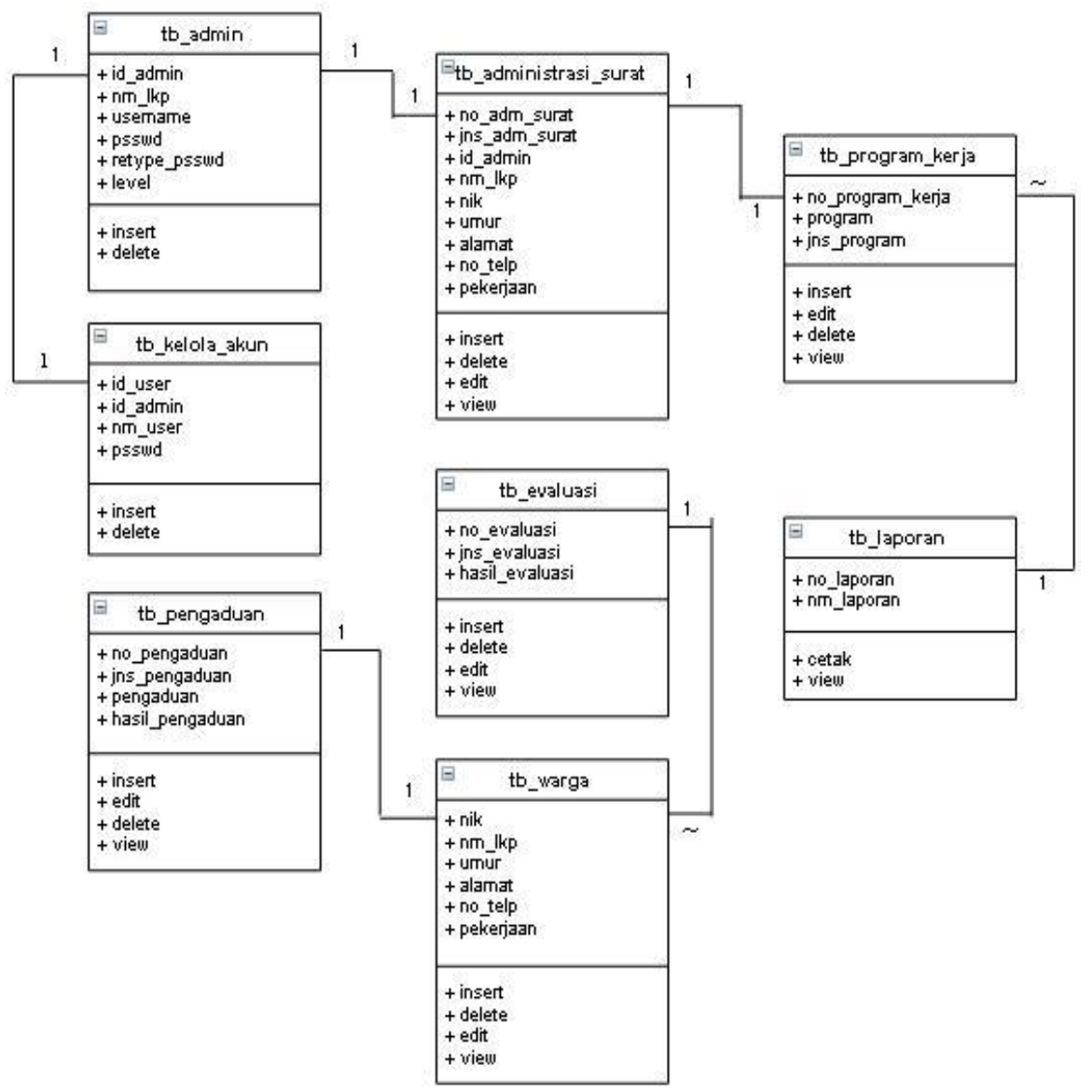

Gambar 6. Class Diagram

\subsection{Pengembangan Sistem}

Metodelogi pengembangan sistem yang digunakan dalam penelitian ini adalah metode prototyping. Penggunaan metode ini didasarkan pada keuntungan dalam mendapatkan umpan balik yang cepat dari user. Gambar dibawah menunjukkan tahapan dari metode prototyping. Tahapan pertama adalah komunikasi dimana pada tahap tersebut dilakukan dengan adanya komunikasi dengan user, selanjutnya tahap perencanaan cepat dan kemudian dilanjutkan ke tahapa perancangan cepat. Setelah tahap perancangan dilanjutkan dengan pembentukan prototyping, kemudian prototyping diberikan kepada user untuk di review dan diberikan umpan balik yang cepat [13]. 


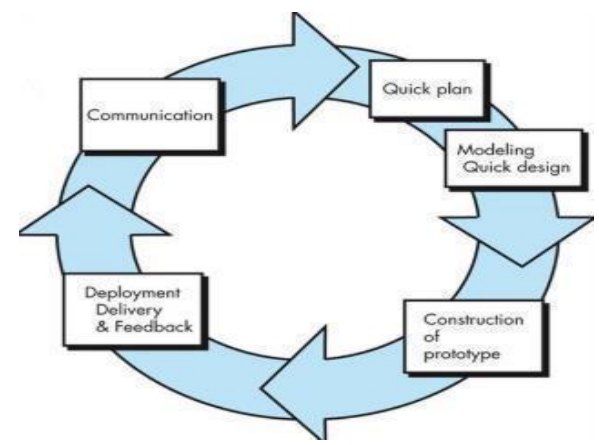

Gambar 7. Metode Prototyping (Pressman \& Maxim, 2014)

\subsection{Perancangan Interface Pelayanan Publik}

Perancangan interface dari pelayanan publik ini adalah sebagai berikut :

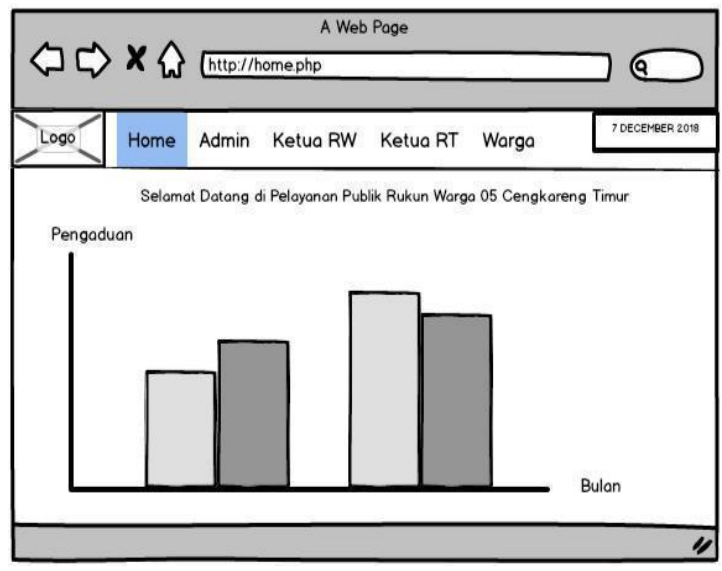

Gambar 8. Interface Pelayanan Publik

Rancangan interface pada gambar diatas dalam pelayanan public pada wilayah rukun warga 05 cengkareng timur yang akan digunakan oleh actor staff yang akan melakukan penginputan.

\subsection{Perancangan Surat Keterangan Tidak Mampu}

Tampilan ini adalah salah satu contoh dari pelayanan publik administrasi surat yang ada di Rukun Warga 05 Cengkareng Timur. Pada gambar berikut adalah tampilan data-data warga yang mengurus surat keterangan tidak mampu.

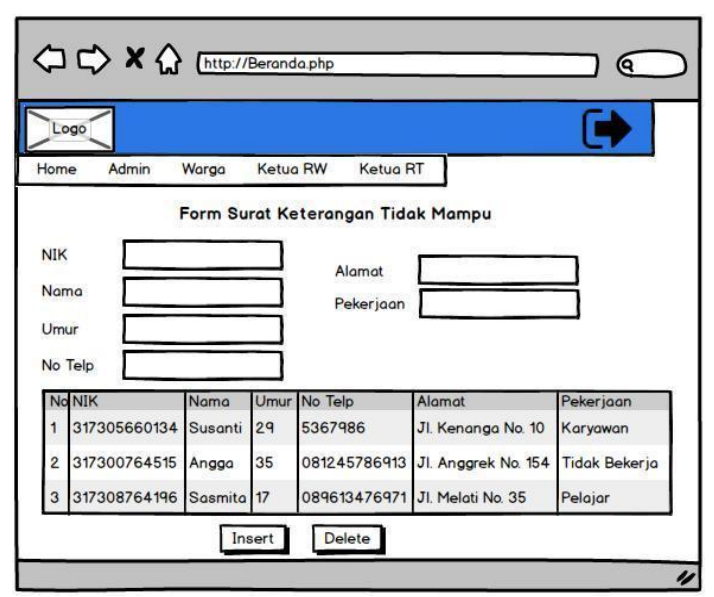

Gambar 9. Rancangan Surat Keterangan Tidak Mampu 


\section{KESIMPULAN DAN SARAN}

Pemanfaatan sistem informasi pelayanan publik memudahkan rukun warga dalam mengelola administrasi dan birokrasi pelayanan warga. Dokumentasi proses transaksi bisnis dapat dikelola dengan lebih baik karena menggunakan sistem basis data yang dapat menjaga konsistensi dan keamanan data. Sistem ini juga diharapkan bisa menjadi solusi dalam pemberian SKTM sehingga dapat meminimalisir penyalahgunaan pemberian SKTM kepada masyarakat yang tepat sasaran.

Adapun saran-saran yang diberikan untuk pengembangan selanjutnya terhadap aplikasi web ini adalah sebagai berikut : Mengembangkan website menjadi mobile application, kriteria yang digunakan masih belum menjangkau semua aspek dasar kemiskinan serta karena keadaan sering berubah-ubah, untuk kedepannya data hasil penunjang belum mampu digunakan untuk waktu jangka panjang.

\section{DAFTAR PUSTAKA}

[1] Ridwan, Juniarso, \& Sodik Sudrajat, Achmad. 2009. Hukum Administrasi Negara dan Kebijakan Pelayanan Publik. Bandung:Nuansa

[2] Ediansa, Oka, \& Roestam, Rusdianto. 2018. Analisis dan Perancangan Sistem Penunjang Keputusan Warga Miskin Penerima SKTM Pada Pemerintah Kota Jambi. Jurnal Manajemen Sistem Informasi. Vol 3, No.1, Maret 2018

[3] Hidayatulloh, Sayrif, \& Mulyadi Cisde. Sistem Pelayanan Administrasi Kependudukan Desa Candigatak Berbasis Web. Jurnal IT CIDA. Vol 1 No.1, Desember 2015

[4] Wasiati, Hera,. \& Wijayanti, Dwi. 2014. Sistem Pendukung Keputusan Penentuan Kelayakan Calon Tenaga Kerja Indonesia Menggunakan Metode Nä̈ve Bayes. Indonesian Journal on Networking and Security. Vol 3 No.2, 2014

[5] Purba, Ramen Antonov. 2016. Sistem Pendukung Keputusan Untuk Menentukan Kualitas Buah Jeruk Dengan Menerapkan Metode Bayes (Studi Kasus:Kabupaten Karo). Seminar Teknologi Informasi dan Komunikasi. Yogyakarta, 18-19 Maret 2016

[6] Septriyaningrum, Indah Ayu., Nugrahadi, Gogon T., \& Ridwan, Ichsan. 2016. Perancangan dan Pengembangan Prototype Sistem Parkir. Kumpulan Jurnal Ilmu Komputer. Vol 03, No. 2, September 2016

[7] Pradipta, Afghan Amar., Prasetyo Yuli Adam., \& Ambarsari, Nia. 2015. Pengembangan Web E-Commerce Bojana Sari Menggunakan Metode Prototype. E-Proceeding Of Engineering. Vol 2 No.1, April 2015

[8] Ardiansyah, \& Harnaida Fitria. 2017. Sistem Informasi IT Asset Management Berbasis Web Menggunakan Framework Codeigniter Pada PT. Aero Systems Indonesia (ASYST). Jurnal Sistem Informasi Teknologi Informatika dan Komputer. Vol 8 No.1, 2017

[9] Masya, Fajar., Prastiawan, Hendra., \& Putri Destriyani. 2017. Design and Implementation of Lecturer Evaluation System Using ELECTRE Method in Web-based Application. International Research Journal Of Science Computer. Issue 5 Vol 4, May 2017

[10] Pressman, R.S. 2015. Rekayasa Perangkat Lunak: Pendekatan Praktisi Buku I. Yogyakarta: Andi

11] Pratiwi, Heny. 2016. Buku Ajar Sistem Pendukung Keputusan. Yogyakarta : Deepublish

[12] Dennis, Alan. 2015. System Analysis and Design with UML $5^{\text {th }}$ Edition. United States of America: John Wiley and Sons.

[13] Pressman, R.S., \& Maxim, B.R. 2014. Software Engineering a Practitioner's Approach $8^{\text {th }}$ Edition 